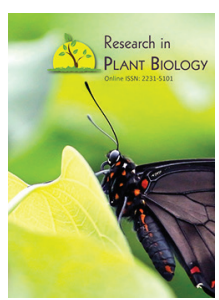

ISSN: $2231-5101 X$

\title{
Micropropagation, genetic fidelity assessment and phytochemical studies of Clerodendrum thomsoniae Balf. f. with special reference to its anti-stress properties
}

\author{
Pallab Kar', Arnab Kumar Chakraborty', Malay Bhattacharya², \\ Tanmayee Mishra² and Arnab Sen ${ }^{1 *}$ \\ ${ }^{1}$ Molecular Genetics Laboratory, Department of Botany, University of North Bengal, Siliguri-734013, India, \\ ${ }^{2}$ Molecular Biology and Tissue Culture Laboratory, Department of Tea Science, University of North Bengal, \\ Siliguri- 734013, India
}

\begin{abstract}
Clerodendrum thomsoniae commonly known as bleeding heart vine or bag flower. In this study, in-vitro callus regeneration of C. thomsoniae through nodal culture has been tried. Murashige and Skoog's medium (MS) with BAP was found suitable for shoot and root development. To detect clonal fidelity in C. thomsoniae, RAPD and ISSR markers were used. Ten RAPD decamers produced 65 amplicons, while ten ISSR primers generated 75 bands in both in-vitro plantlets and mother plants. The amplified products of parent plants and the regenerated plants were found to be monomorphic in RAPD and ISSR analyses. A number of compounds with potential therapeutic and biological activity had been detected with the help of GC-MS analysis. Among this the compounds namely 3-Hydroxybutyric acid, Azelaic acid, Linoleic acid, Oleic acid, Squalene, Stigmasterol are the important compounds mainly responsible for anti-cancer, anti-inflammatory, antiasthma, antimicrobial, antistress activity and so on. Taking into account of all the GC-MS and in-silico molecular docking data, it can be concluded that some of these compounds may be potential to future drug industry.
\end{abstract}

Received: February 01, 2019

Accepted: March 03, 2019

*Corresponding Author:

Arnab Sen

Email: senarnab_nbu@

hotmail.com

KEYWORDS: Clerodendrum thomsoniae, RAPD, ISSR, nodal stem segment, genetic fidelity, GC-MS

\section{INTRODUCTION}

India has a long tradition of growing ornamental flowers that have recently been exploited both in domestic and international market [1]. However, due to the never ending search of the customers for new flowering plants lead the floriculture industries to explore the new species. Bleeding heart vine (Clerodendrum thomsoniae) belonging to the family Lamiaceae, is a potent ornamental plant recently exploited by the floriculture industries [2]. Floriculture industry mainly depends on two important components, firstly, trade of flowering inflorescences and type of foliage, and secondly, supply of nursery stocks such as tubers, seeds, bulbs, cutting-raised plants and tissue culture raised plantlets [3].Propagation through conventional techniques have some limitations and cannot fulfill the high demand of ornamental plants, therefore, there is in need of urgent attention for in-vitro multiplication [4].
Clerodendrum thomsoniae is a well known cultivated ornamental plant with beautiful flowers and has been extensively used in the horticulture as pot plants for its attractive flowers. The species is relatively new to the floriculture industry because unavailability and lesser number of seed production. C. thomsoniae is a rambling, twining, vine like shrub native to tropical West Africa. Bleeding-heart vine or Bag-flower is the common name of Clerodendrum thomsoniae [5,4].

Apart from having immense floriculture and horticulture importance, this plant has been utilized in traditional medicine. The other members of the genus Clerodendrum like C. indicum, C. viscosum, C. serratum, C. colebrookianum etc. are medicinal and used as folk medicine [6-9]. The leaves and flowers of C. thomsoniae are the main sources of several medicinally important phytocompounds. These phytocompounds protect human body from oxidative stress by its own competent defense mechanism and curing diversified diseases like bruises, cuts, skin

Copyright: $\odot 2019$ The authors. This article is open access and licensed under the terms of the Creative Commons Attribution License (http://creativecommons.org/licenses/by/4.0/) which permits unrestricted, use, distribution and reproduction in any medium, or format for any purpose, even commercially provided the work is properly cited. Attribution - You must give appropriate credit, provide a link to the license, and indicate if changes were made. 
rashes and sores etc. [10]. Oxidative stress induced by reactive oxygen and nitrogen species (ROS and RNS) is a major causative agent in the induction of several brain disorders including neurogenerative diseases [11] and depression [12].

Apart from some studies on propagation, plant growth retardants etc., no attempt so far has been made to regenerate C. thomsoniae through in-vitro methods. However, proper molecular characterization and profiling of phytochemical constituents of $\mathrm{C}$. thomsoniae still remains largely obscure. So, initiatives were taken to explore molecular biology and medicinal property detection through GC-MS. Keeping all these lacunae in mind, the aim of the present study is to standardize the working protocol of regeneration of $C$. thomsoniae by way of regeneration through callus culture, detection of somaclonal variations, if any and medicinal characterization of both the mother plant and tissue culture raised plantlets. Within the same scope we will try to evaluate whether the bioactive compounds present in C. thomsoniae could be responsible for reducing depression with an in-silico molecular docking approach.

\section{MATERIALS AND METHODS}

\section{Establishment of Aseptic Culture}

The nodal segments of $C$. thomsoniae were collected from our laboratory garden for aseptic culture. The explants were washed in $1 \%$ tween 20 for 30 minutes and then rinsed several times with double distilled water (DDW). The explants were then surface sterilized with $0.1 \% \mathrm{HgCl}_{2}$ for $5 \mathrm{~min}$ and then rinsed several times with sterile DDW. Explants were finally treated with $70 \%$ alcohol for 45 seconds and washed several times with sterile DDW to remove the traces of alcohol. The explants were then trimmed to approximately $3 \mathrm{~cm}$. in length and blot dried. All these operations were conducted under aseptic environment of laminar air flow cabinet.

\section{Callus Culture and Plantlet Regeneration}

The trimmed explants were aseptically inoculated in MS medium [13] and Woody Plant medium [14], containing various concentration of growth regulators (BAP and NAA) along with three different concentrations of sucrose (Table 1) and $0.8 \%$ agar. The $\mathrm{pH}$ of the media was adjusted to 5.6-5.8 before adding agar and autoclaved at $121^{\circ} \mathrm{C}$ for $20 \mathrm{~min}$ at $15 \mathrm{psi}$.

Different concentrations of cytokinins like BAP (6-benzyl amino purine) and auxins like NAA (1-napthaleneacetic acid) were used in this study for initiation of callus and shoot. Controlled cultures with no hormone were also prepared. Sub-culturing was done at 2 weeks interval in the same media having the same hormonal composition [15]. BAP was applied at the rate of 1,2, 3 and $4 \mathrm{mg} / \mathrm{l}$ and NAA at the rate of $0.5 \mathrm{mg} / \mathrm{l}$ to observe various stages of in-vitro callusing and subsequent shoot formation. The cultures were incubated under 2000-3000 lux light intensity for $16 \mathrm{~h} /$ day at $25^{\circ} \pm 2^{\circ} \mathrm{C}$ temperature. Root initiation and growth took place in the same media used for callus culture.
Table 1: Effect of sucrose on regeneration of shoot buds from callus of $C$. thomsoniae

\begin{tabular}{lccc}
\hline BAP $(\mathrm{mg} / \mathrm{l})$ & NAA $(\mathrm{mg} / \mathrm{l})$ & Sucrose $(\%)$ & Mean no. of shoots/callus \\
\hline $1 \mathrm{mg} / \mathrm{l}$ & $0.5 \mathrm{mg} / \mathrm{l}$ & 1 & $2.76 \pm 0.39$ \\
& & 2 & $3.71 \pm 0.25$ \\
& & 3 & $6.5 \pm 0.5$ \\
$2 \mathrm{mg} / \mathrm{l}$ & $0.5 \mathrm{mg} / \mathrm{l}$ & 1 & $6.98 \pm 0.21$ \\
& & 2 & $9.07 \pm 0.17$ \\
& & 3 & $13 \pm 1.5$ \\
$3 \mathrm{mg} / \mathrm{l}$ & $0.5 \mathrm{mg} / \mathrm{l}$ & 1 & $7.54 \pm 0.24$ \\
& & 2 & $8.24 \pm 0.30$ \\
$4 \mathrm{mg} / \mathrm{l}$ & $0.5 \mathrm{mg} / \mathrm{l}$ & 3 & $9.5 \pm 0.5$ \\
& & 2 & $1.31 \pm 0.21$ \\
& & 3 & $2.5 \pm 0.10$ \\
& & 2 & $4 \pm 1.0$ \\
\hline
\end{tabular}

\section{Hardening and Transfer of Plants to Soil}

After 4 weeks of in-vitro root development, the plantlets were carefully taken out of the culture bottle without causing much damage to the plant parts. The roots were washed gently under running tap water to completely remove the medium. Then the plantlets were transferred to a mixture of sandy soil and farm yard manure with a ratio of 1:1 $(\mathrm{v} / \mathrm{v})$. Hardening of plantlets was conducted for 30 days in green house condition and was finally transferred to the field. The survival percentage of the acclimatized plantlets was recorded.

\section{Molecular Analysis}

The genomic DNA of field grown plant and the in-vitro propagated plantlets was extracted using Genelute Plant Genomic DNA kit (Sigma, St. Louis, MI, USA, Cat\# G2N-70). Based on the spectrophotometric analysis, the DNA was diluted to a concentration of $25 \mathrm{ng} / \mu \mathrm{l}$. Initially, a total of $20 \mathrm{RAPD}$ and 15 ISSR primers were screened for PCR amplification. Both RAPD and ISSR amplifications were performed using $25 \mu \mathrm{L}$ of PCR mixture containing 12.5 $\mu$ l PCR Master Mix 2X (Promega, Cat\# M7122), $1.25 \mu \mathrm{l}$ of primer $(0.25 \mu \mathrm{m}), 2 \mu \mathrm{l}$ of template DNA $(25 \mathrm{ng} / \mu \mathrm{l})$ and Pyrogen-free water to a final volume of $25 \mu \mathrm{l}$. The PCR reactions were performed on an Applied Biosystems Thermocycler 2720. The amplification condition of RAPD was $94^{\circ} \mathrm{C}$ for $4 \mathrm{~min}$, followed by 40 cycles of amplification with $1 \mathrm{~min}$ denaturation at $94^{\circ} \mathrm{C}, 1 \mathrm{~min}$ annealing at $37^{\circ} \mathrm{C}, 2 \mathrm{~min}$ primer extension at $72{ }^{\circ} \mathrm{C}$, and a final extension at $72{ }^{\circ} \mathrm{C}$ for $10 \mathrm{~min}$. The conditions of the thermal cycle for ISSR amplifications were $94^{\circ} \mathrm{C}$ for $5 \mathrm{~min}$, followed by 35 cycles of amplification having $45 \mathrm{~s}$ for denaturation at $94^{\circ} \mathrm{C}, 1 \mathrm{~min}$ annealing at $52^{\circ} \mathrm{C}, 1 \mathrm{~min}$ primer extension at $72{ }^{\circ} \mathrm{C}$, and a final extension at $72{ }^{\circ} \mathrm{C}$ for $7 \mathrm{~min}$. The PCR products were electrophoresed on $1.5 \%(\mathrm{w} / \mathrm{v})$ agarose gel with two DNA markers- $\lambda$ DNA/EcoRI/HindIII double digest (Chromous Biotech, Cat\# MAN 06) and a 100 base pair (bp) DNA ladder (Chromous Biotech, Cat\# LAN 02), and were photographed with Gel Documentation system (UVi).

\section{GC-MS Analysis}

The bio-active compounds of the mother and tissue cultured plants were identified by GC-MS analysis according to standard methods with slight modifications [16]. 

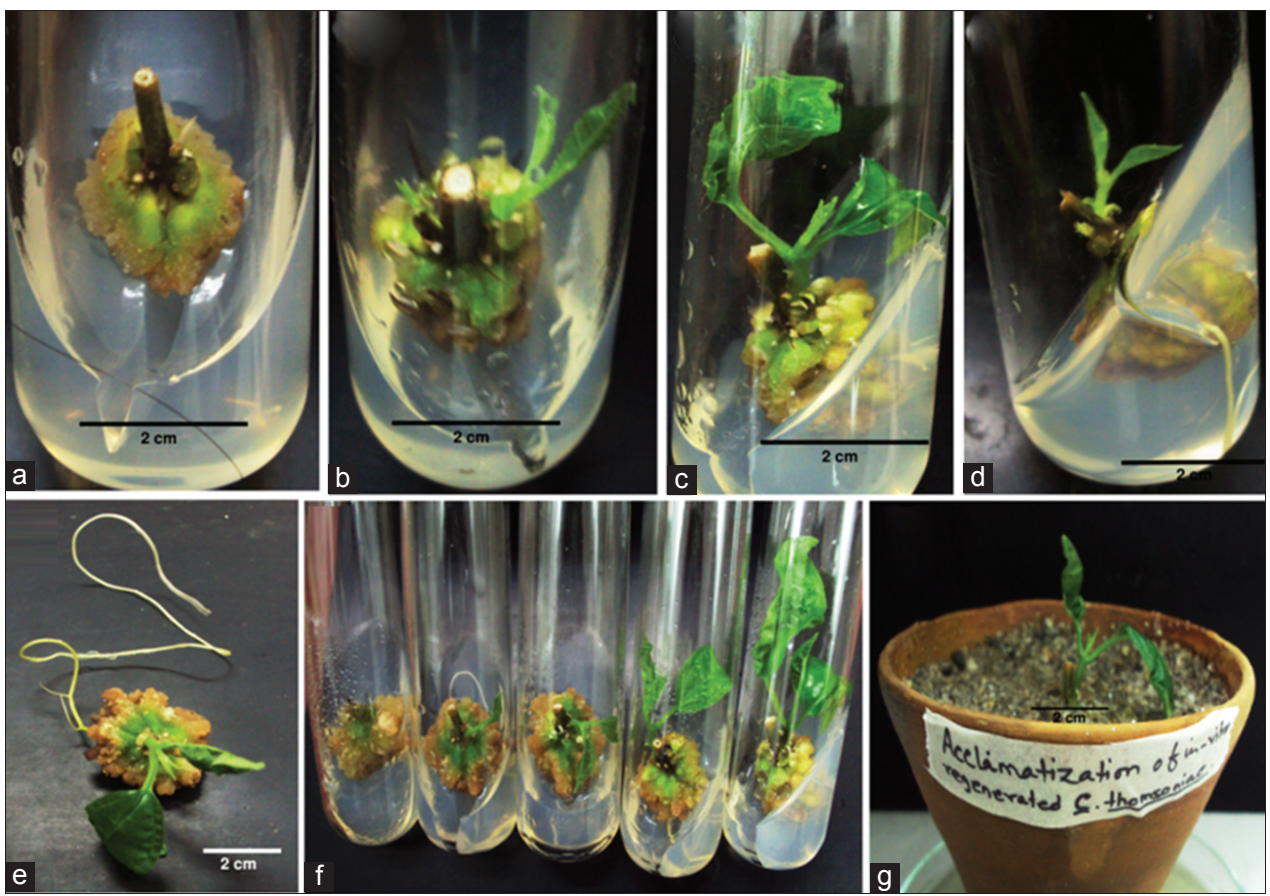

Figure 1: Stages of callus induction and regeneration. (a) Callus induction; (b) Formation of in-vitro shoot; (c) Development of leaves; (d) In-vitro root induction; (e) Plantlet with well developed roots; (f) Different stages of shoot induction; (g) Acclimatization of plant in clay pot containing mixture of soil and sand.

Table 2: Effect of different concentrations of BAP with the optimal concentrations of NAA on callus induction from nodal segments of $C$. thomsoniae

\begin{tabular}{ccccc}
\hline Medium & \multicolumn{2}{c}{ Plant growth regulators (mg/l) } & & Callus induction frequency (\%) \\
\cline { 2 - 4 } & BAP & NAA & 0 & Mean weight of the callus (gm) \\
\hline \multirow{3}{*}{ MS } & 0 & 0 & 25 & 0.0 \\
& 1 & 0.5 & 85 & $0.11 \pm 0.015$ \\
& 2 & 0.5 & 40 & $0.56 \pm 0.076$ \\
& 3 & 0.5 & 30 & $0.3 \pm 0.02$ \\
& 4 & 0.5 & $0.2 \pm 0.025$ \\
\hline
\end{tabular}

\section{Molecular Docking}

The most prominent and active compounds present in tissue cultured plants, detected through GC-MS analysis were subjected to molecular docking analysis against protein. The protein selected here is Brain-derived neurotrophic factor (BDNF) which is proved to play a role in depression [17]. The X-ray crystallographic structure of the protein available in the Protein Data Bank (http://www.rcsb.org) was used. Molecular docking was conducted using AutoDockVina [18].

\section{Statistical Analysis}

All the experiments were repeated thrice with minimum 10 explants each. The values were presented as a mean $\pm \mathrm{SE}$ of three experiments. The data were analyzed by Student's unpaired $t$ test and treatment mean values were compared at $P \leq 0.05-0.01$.

\section{RESULTS AND DISCUSSION}

\section{Establishment of Aseptic Culture}

Fungal and bacterial contamination was the main problem during the early stage of the culture initiation. To avoid this problem various surface sterilants (tween $20,70 \%$ ethanol, $0.1 \%$ mercuric chloride solution) were used Almost similar methods like $70 \%$ ethanol and $0.1 \%$ mercuric chloride $\left(\mathrm{HgCl}_{2}\right)$ have been used to disinfect the explants of Clerodendrum inerme [19]. Labolene $(5 \%)$ in combination with $0.1 \% \mathrm{HgCl}_{2}$ has been used in the tissue culture study of Clerodendrum serratum by Sharma and his coworkers [20].

\section{Callus Induction}

In-vitro maintained nodal explants started swelling within 6-8 days and fully developed callus like structures were observed after 12-15 days of inoculation. All the calli were observed to 
Table 3: Influence of different concentrations of plant growth regulators on regeneration of shoot buds and elongation of proliferated shoots from callus of $C$. thomsoniae

\begin{tabular}{|c|c|c|c|c|}
\hline \multirow[t]{2}{*}{ Medium } & \multicolumn{2}{|c|}{$\begin{array}{l}\text { Plant growth } \\
\text { regulators }(\mathrm{mg} / \mathrm{l})\end{array}$} & \multirow[t]{2}{*}{$\begin{array}{c}\text { Mean no. of shoots/ } \\
\text { callus }\end{array}$} & \multirow[t]{2}{*}{$\begin{array}{l}\text { Mean shoot } \\
\text { length }(\mathrm{cm})\end{array}$} \\
\hline & BAP & NAA & & \\
\hline \multirow{5}{*}{ MS } & 0 & 0 & 0.0 & 0.0 \\
\hline & 1 & 0.5 & $6.5 \pm 0.5$ & $1.33 \pm 0.3 * *$ \\
\hline & 2 & 0.5 & $13 \pm 1.5$ & $3.5 \pm 0.5 * *$ \\
\hline & 3 & 0.5 & $9.5 \pm 0.5$ & $2.3 \pm 0.15^{* *}$ \\
\hline & 4 & 0.5 & $4 \pm 1.0$ & $1.6 \pm 0.07^{\mathrm{NS}}$ \\
\hline
\end{tabular}

Data expressed as mean \pm S.D $(n=3) .{ }^{*} p<0.01 ;{ }^{\text {NS }}$-Non significant when compared with mean no. of shoots/callus.

Table 4: Effect of different concentrations of BAP and NAA on rooting of in-vitro raised elongated roots in $C$. thomsoniae

\begin{tabular}{|c|c|c|c|c|}
\hline \multirow[t]{2}{*}{ Medium } & \multicolumn{2}{|c|}{$\begin{array}{l}\text { Plant growth } \\
\text { regulators }(\mathrm{mg} / \mathrm{l})\end{array}$} & \multirow[t]{2}{*}{$\begin{array}{c}\text { Mean no. of roots/ } \\
\text { explant }\end{array}$} & \multirow[t]{2}{*}{$\begin{array}{l}\text { Mean root } \\
\text { length }(\mathrm{cm})\end{array}$} \\
\hline & BAP & NAA & & \\
\hline \multirow{5}{*}{ MS } & 0 & 0 & 0.0 & 0.0 \\
\hline & 1 & 0.5 & $1.33 \pm 0.35$ & $7.8 \pm 0.76 * *$ \\
\hline & 2 & 0.5 & $3.5 \pm 0.5$ & $21.3 \pm 1.52$ ** \\
\hline & 3 & 0.5 & $1.9 \pm 0.13$ & $13 \pm 1.0 * *$ \\
\hline & 4 & 0.5 & $1.7 \pm 0.05$ & $10.5 \pm 0.5 * *$ \\
\hline
\end{tabular}

Data expressed as mean \pm S.D $(n=3) .{ }^{*} p<0.01$ when compared with mean no. of roots/explants.

Table 5: PCR amplification using RAPD and ISSR primers

\begin{tabular}{|c|c|c|c|c|}
\hline Primer ID & $\begin{array}{l}\text { Primer } \\
\text { sequence }\left(5^{\prime}-3^{\prime}\right)\end{array}$ & $\begin{array}{c}\text { Total bands } \\
\text { amplified }\end{array}$ & $\begin{array}{l}\text { No. of } \\
\text { monomorphic } \\
\text { bands }\end{array}$ & Band size (bp) \\
\hline OPA 01 & CAGGCCСТTC & 4 & 4 & $324-1310$ \\
\hline OPA 02 & TGCCGAGCTG & 8 & 8 & $325-1646$ \\
\hline OPA 03 & AGTCAGCCAC & 13 & 13 & 224-1434 \\
\hline OPA 07 & GAAACGGGTG & 3 & 3 & $220-1128$ \\
\hline OPA 08 & GTGACGTAGG & 5 & 5 & $357-1453$ \\
\hline OPA 09 & GGGTAACGCC & 4 & 4 & $286-1218$ \\
\hline OPA 10 & GTGATCGCAG & 7 & 7 & $346-1605$ \\
\hline OPA 11 & CAATCGCCGT & 5 & 5 & $383-1383$ \\
\hline OPA 12 & CAGCACCCAC & 9 & 9 & $459-1544$ \\
\hline OPA 18 & AGGTGACCGT & 7 & 7 & $363-1589$ \\
\hline Total bands & & 65 & 65 & \\
\hline UBC 807 & $(A G) 8 T$ & 7 & 7 & $226-949$ \\
\hline UBC 808 & $(A G) 8 C$ & 8 & 8 & $139-1340$ \\
\hline UBC 810 & $(G A) 8 T$ & 12 & 12 & $225-935$ \\
\hline UBC 811 & $(G A) 8 C$ & 6 & 6 & $185-847$ \\
\hline UBC 813 & (CT) $8 \mathrm{~T}$ & 3 & 3 & $250-975$ \\
\hline UBC 815 & (CT) $8 \mathrm{G}$ & 4 & 4 & $425-1260$ \\
\hline UBC 818 & $(C A) 8 G$ & 8 & 8 & $326-1030$ \\
\hline UBC 822 & (TC) $8 \mathrm{~A}$ & 8 & 8 & $288-1250$ \\
\hline UBC 824 & (TC) $8 \mathrm{G}$ & 8 & 8 & $235-1225$ \\
\hline UBC 825 & (AC) 8T & 11 & 11 & $323-1110$ \\
\hline Total bands & & 75 & 75 & \\
\hline
\end{tabular}

be initiated from the cutting edge of the explants (Fig. 1). The calli formed were fast growing, yellowish green and compact. Though in our tissue culture studies, MS and WPM were used for preliminary screening, but better responses were observed in cultures of MS media. So, for propagation of $\mathrm{C}$. thomsoniae only MS was employed for further regeneration. This indicates that some of the essential component required by Clerodendrum for its regeneration is not available in WPM [21]. Similar observation on other species of Clerodendrum tissue culture is available. Callus was induced only when nodal explants were inoculated in MS medium supplemented with BAP and NAA. The callus induction frequency was found optimum in MS medium supplemented with $2 \mathrm{mg} / \mathrm{l} \mathrm{BAP}$ and $0.5 \mathrm{mg} / \mathrm{l} \mathrm{NAA}$ (85\%), followed by $40 \%$ with $3 \mathrm{mg} / \mathrm{l} \mathrm{BAP}$ and $0.5 \mathrm{mg} / \mathrm{l} \mathrm{NAA}$ (Table 2). Further increase in the hormone concentration resulted in reduction of callus formation. In our present study, the highest callus weight $(0.56 \pm 0.076 \mathrm{gm})$ was noted with $2 \mathrm{mg} /$ BAP and $0.5 \mathrm{mg} / \mathrm{l} \mathrm{NAA}$ followed by $3 \mathrm{mg} / \mathrm{l} \mathrm{BAP}$ and $0.5 \mathrm{mg} / \mathrm{l}$ NAA $(0.3 \pm 0.02 \mathrm{gm})$ (Table 2$)$.

\section{Shoot Regeneration}

The regenerative ability of the compact calli was studied by the application of two important plant hormones cytokinins and auxin. After 2 weeks of the culture, most of the calli turned green and emergence of shoot primordia took place (Fig. 1). The number and length of shoots varied with the concentration of phytohormones used. MS medium supplemented with $2 \mathrm{mg} / \mathrm{l}$ BAP in combination with $0.5 \mathrm{mg} / \mathrm{NAA}$ produced the highest number of shoot buds $(13 \pm 1.5)$ followed by $3 \mathrm{mg} / \mathrm{l}$ BAP in combination with $0.5 \mathrm{mg} / \mathrm{l} \mathrm{NAA}(9.5 \pm 0.5)$ (Table 3). BAP is most commonly used cytokinin mainly due to twofold reasons, firstly, it is cheap and secondly, it can be autoclaved [22]. The highest shoot length $(3.5 \pm 0.5 \mathrm{~cm})$ was noted with $2 \mathrm{mg} / \mathrm{l}$ BAP and $0.5 \mathrm{mg} / \mathrm{NAA}$ followed by $2.3 \pm 0.15 \mathrm{~cm}$ with $3 \mathrm{mg} / \mathrm{BAP}$ in combination with $0.5 \mathrm{mg} / \mathrm{NAA}$. In the present workflow, BAP was found to be rather effective incase of shoot multiplication. These findings are in accordance with the earlier work on in-vitro propagation of other Clerodendrum species like C. inerme [19], C. serratum [20], C. colebrookianum [23], C. inerme [24] where BAP has been widely used and was found to be effective.

In our present experiment, it was noted that root development took place without changing the medium and hormones. In BAP assisted with MS, rooting was initiated little later $10 \pm$ 3 days after shoot development. About $90 \%$ of shoots rooted in MS medium supplemented with $2 \mathrm{mg} / \mathrm{BAP}$ in combination with $0.5 \mathrm{mg} / 1 \mathrm{NAA}$. The highest number of roots $(3.5 \pm 0.5)$ and maximum length of roots $(21.3 \pm 1.52 \mathrm{~cm})$ were recorded with $2 \mathrm{mg} / \mathrm{l}$ BAP with $0.5 \mathrm{mg} / \mathrm{l}$ NAA followed by $3 \mathrm{mg} / \mathrm{l}, 4 \mathrm{mg} / \mathrm{l}$ BAP (Table 4; Fig. 1).

\section{Acclimatization of In-vitro Regenerated Plants}

The in-vitro propagated plantlets were successfully transferred to clay pots containing sandy soil and farm yard manure in a ratio of $1: 1(\mathrm{v} / \mathrm{v})$ exhibited $70 \%$ survival rate and grew in the greenhouse (Fig. 1). After a month, these acclimatized plants were successfully transferred to the field.

\section{Genetic Fidelity among in-vitro Raised Plantlets}

Plantlets regenerated indirectly from the nodal explants via callus culture were used for the study of somaclonal variations. No differences were detected by RAPD and ISSR analysis in 


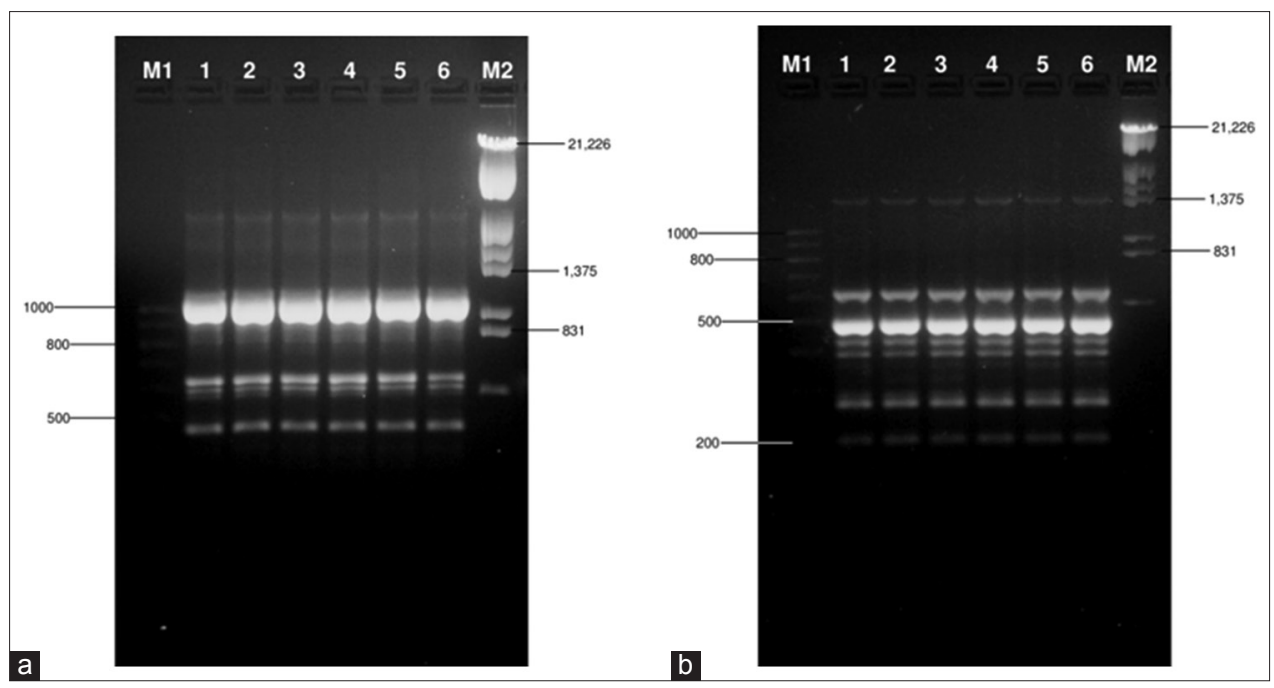

Figure 2: DNA fingerprinting pattern of in-vitro callus regenerated plantlets of $C$. thomsoniae. (a) using RAPD primer OPA 13 and (b)using ISSR primer UBC 808. Lane 2-6: micropropagated plantlets compared with mother plant (lane1); Lane M1: 100 bp molecular marker; Lane M2: $\lambda$ DNA/EcoRI/HindIII double digest DNA ladder.

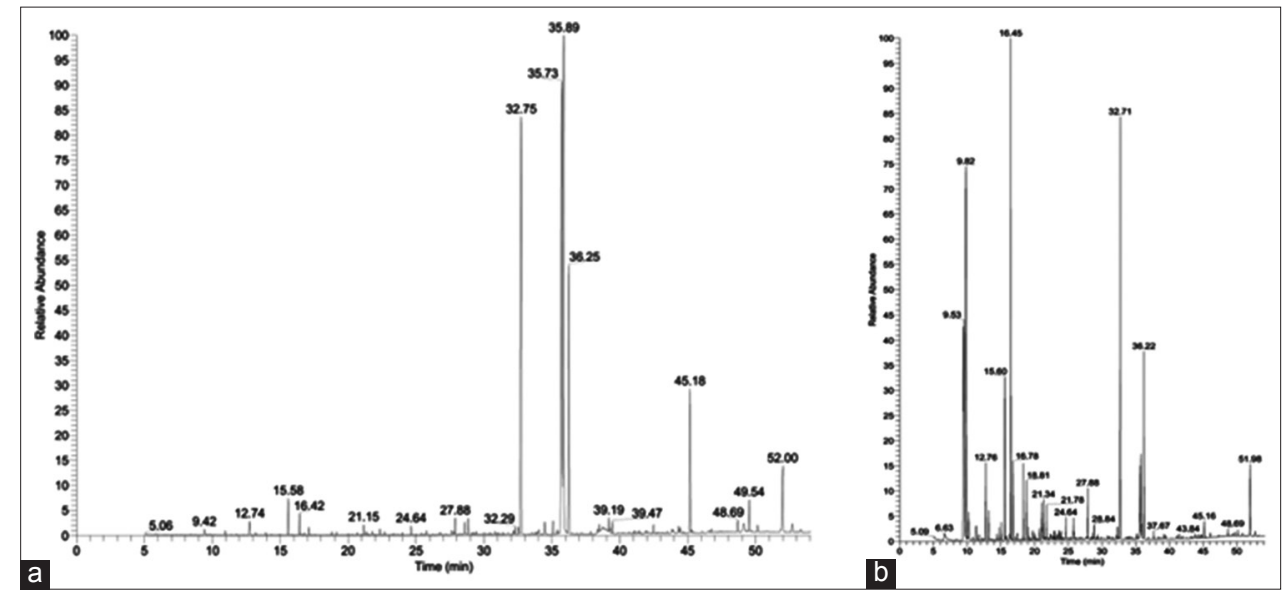

Figure 3: GC-MS fingerprinting of (a) mother plant and (b) tissue culture plant.

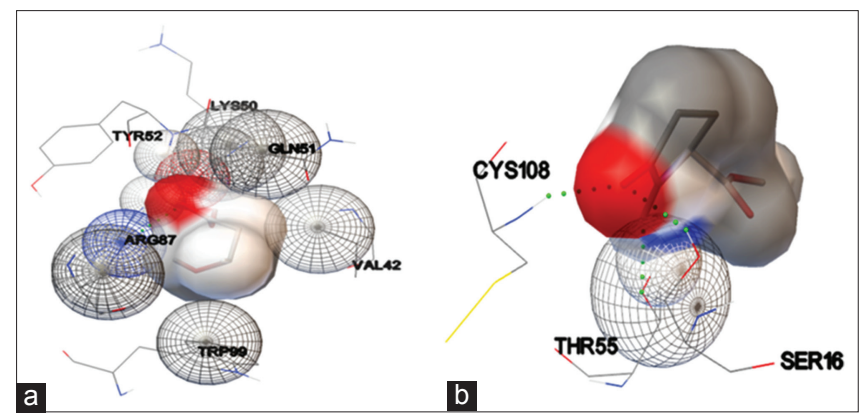

Figure 4: Molecular surface view of BDNF protein with (a) 3-Hydroxybutyric acid and (b) Pyroglutamic acid docked into its binding site.

between the genetic material of mother plant and plantlets regenerated from nodal explants. A total of 45 primers (30 RAPD and 15 ISSR) were used to screen somaclonal variations, of which clear and scorable amplification products were produced by 10 each RAPD and ISSR primers. Distinct and scorable bands were obtained from the RAPD analysis (65) and ISSR analysis (75) (Table 5). In case of RAPD primers number of bands varied from 3-13 whereas in case of ISSR primers the number of bands ranged from 3-12. All the bands generated through both RAPD and ISSR analyses were found to be monomorphic i.e. bands generated were common in parental genotypes and the in-vitro raised plantlets. A representative of RAPD and ISSR profile is depicted in Fig. 2. Our fingerprint analyses confirm genetic stability and clonal fidelity of $\mathrm{C}$. thomsoniae. Importance of RAPD and ISSR fingerprints to detect clonal fidelity of in-vitro raised plantlets has already been reported by Goyal et al. [25].

\section{GC-MS Analysis}

The present study was extended for the analysis pertaining to the identification of active compounds in mother plant and tissue culture plant using GC-MS method. A total number of nineteen (19) and twenty seven (27) phytocompounds have been identified in mother plant and tissue culture plant respectively (Table 6), which corresponds to Fig. 3. Ten 
Table 6: List of phytocompounds identified in C. thomsoniaeleaf extract (mother plant and tissue culture plant) by GC-MS analysis

\begin{tabular}{|c|c|c|c|c|c|}
\hline SI. No. & Compound name & Formula & Mol. Wt. $\dagger$ & Mother plant & Tissue culture plant \\
\hline 1. & Acetic acid & $\mathrm{C}_{2} \mathrm{H}_{4} \mathrm{O}_{2}$ & 55 & $x$ & $\checkmark$ \\
\hline 2. & Propanoic acid & $\mathrm{C}_{3}^{2} \mathrm{H}_{6}^{4} \mathrm{O}_{2}^{2}$ & 73 & $x$ & $\checkmark$ \\
\hline 3. & 3-Hydroxy-2-butanone & $\mathrm{C}_{4}^{3} \mathrm{H}_{8}^{6} \mathrm{O}_{2}^{2}$ & 87 & $x$ & $\checkmark$ \\
\hline 4. & Glyceric acid & $\mathrm{C}_{3}^{4} \mathrm{H}_{6}^{8} \mathrm{O}_{3}^{2}$ & 89 & $\checkmark$ & $\times$ \\
\hline 5. & 3-Hydroxybutyric acid & $\mathrm{C}_{4}^{3} \mathrm{H}_{8}^{0} \mathrm{O}_{3}^{3}$ & 103 & $x$ & $\checkmark$ \\
\hline 6. & Diethylene glycol & $\mathrm{C}_{4} \mathrm{H}_{10} \mathrm{O}_{3}$ & 105 & $x$ & $\checkmark$ \\
\hline 7. & 2-Furancarboxylic acid & $\mathrm{C}_{5}^{4} \mathrm{H}_{4} \mathrm{O}_{3}$ & 111 & $x$ & $\checkmark$ \\
\hline 8. & 2-Hexenoic acid & $\mathrm{C}_{6}^{3} \mathrm{H}_{10}^{4} \mathrm{O}_{2}^{3}$ & 113 & $\checkmark$ & $\checkmark$ \\
\hline 9. & Butanedioic acid & $\mathrm{C}_{4}^{0} \mathrm{H}_{6} \mathrm{O}_{4}{ }_{4}$ & 117 & $\checkmark$ & $\checkmark$ \\
\hline 10 & 1,2,3-Benzenetriol (pyrogallol) & $\mathrm{C}_{6} \mathrm{H}_{6} \mathrm{O}_{3}$ & 125 & $x$ & $\checkmark$ \\
\hline 11 & Pyroglutamic acid & $\mathrm{C}_{5} \mathrm{H}_{7} \mathrm{NO}_{3}$ & 127 & $x$ & $\checkmark$ \\
\hline 12. & Pentanedioic acid (Glutaric acid) & $\mathrm{C}_{5} \mathrm{H}_{8} \mathrm{O}_{4}$ & 131 & $\checkmark$ & $\checkmark$ \\
\hline 13. & Malic acid & $\mathrm{C}_{4} \mathrm{H}_{6} \mathrm{O}_{5}$ & 133 & $\checkmark$ & $x$ \\
\hline 14. & 1,2-Ethanediol, phenyl & $\mathrm{C}_{8}^{4} \mathrm{H}_{10} \mathrm{O}_{2}$ & 137 & $\times$ & $\checkmark$ \\
\hline 15. & Benzoic acid, 3-hydroxy (m-Salicylic acid) & $\mathrm{C}_{7} \mathrm{H}_{6} \mathrm{O}_{3}$ & 137 & $\times$ & $\checkmark$ \\
\hline 16. & 4-Hydroxyphenylethanol (Tyrosol) & $\mathrm{C}_{8} \mathrm{H}_{10} \mathrm{O}_{2}$ & 137 & $\times$ & $\checkmark$ \\
\hline 17. & Adipic acid & $\mathrm{C}_{6} \mathrm{H}_{10} \mathrm{O}_{4}$ & 145 & $x$ & $\checkmark$ \\
\hline 18. & Heptanedioic acid (Pimelic acid) & $\mathrm{C}_{7} \mathrm{H}_{12} \mathrm{O}_{4}$ & 159 & $x$ & $\checkmark$ \\
\hline 19. & Octanedioic acid (Suberic acid) & $\mathrm{C}_{8} \mathrm{H}_{14} \mathrm{O}_{4}$ & 173 & $\times$ & $\checkmark$ \\
\hline 20. & 1-Dodecanol & $\mathrm{C}_{12} \mathrm{H}_{26} \mathrm{O}$ & 185 & $x$ & $\checkmark$ \\
\hline 21. & Azelaic acid & $\mathrm{C}_{9} \mathrm{H}_{16} \mathrm{O}_{4}$ & 187 & $\checkmark$ & $\checkmark$ \\
\hline 22. & Dodecanoic acid (lauricaicd) & $\mathrm{C}_{12} \mathrm{H}_{24} \mathrm{O}_{2}$ & 200 & $\checkmark$ & $\checkmark$ \\
\hline 23. & Ethyl tartrate & $\mathrm{C}_{8} \mathrm{H}_{14} \mathrm{O}_{6}$ & 205 & $\times$ & $\checkmark$ \\
\hline 24. & Tetradecanoic acid & $\mathrm{C}_{14} \mathrm{H}_{28} \mathrm{O}_{2}$ & 227 & $\checkmark$ & $\checkmark$ \\
\hline 25. & Hexadecanoic acid (Palmitic acid) & $\mathrm{C}_{16} \mathrm{H}_{32} \mathrm{O}_{2}$ & 255 & $\checkmark$ & $\checkmark$ \\
\hline 26. & Heptadecanoic acid & $\mathrm{C}_{17} \mathrm{H}_{34} \mathrm{O}_{2}$ & 269 & $\checkmark$ & $\times$ \\
\hline 27. & Linoleic acid & $\mathrm{C}_{18} \mathrm{H}_{32} \mathrm{O}_{2}$ & 279 & $\checkmark$ & $\checkmark$ \\
\hline 28. & Oleic acid & $\mathrm{C}_{18} \mathrm{H}_{34} \mathrm{O}_{2}$ & 281 & $\times$ & $\checkmark$ \\
\hline 29. & Stearic acid & $\mathrm{C}_{18} \mathrm{H}_{36} \mathrm{O}_{2}$ & 283 & $\checkmark$ & $\times$ \\
\hline 30. & 2-Hexadecen-1-ol, 3,7,11,15-tetramethyl & $\mathrm{C}_{20} \mathrm{H}_{40} \mathrm{O}$ & 295 & $\checkmark$ & $\times$ \\
\hline 31. & Eicosanoic acid & $\mathrm{C}_{20} \mathrm{H}_{40} \mathrm{O}_{2}$ & 311 & $\checkmark$ & $\times$ \\
\hline 32. & Palmitelaidic acid, trimethylsilyl ester & $\mathrm{C}_{19}^{2} \mathrm{H}_{38} \mathrm{O}_{2} \mathrm{Si}$ & 325 & $\checkmark$ & $\times$ \\
\hline 33. & Heptacosane & $\mathrm{C}_{27} \mathrm{H}_{56}$ & 379 & $\checkmark$ & $x$ \\
\hline 34. & Squalene & $\mathrm{C}_{30} \mathrm{H}_{50}$ & 409 & $\checkmark$ & $\checkmark$ \\
\hline 35. & Stigmasterol & $\mathrm{C}_{29} \mathrm{H}_{48} \mathrm{O}$ & 412 & $\checkmark$ & $\checkmark$ \\
\hline 36. & $\alpha$-Tocopherol & $\mathrm{C}_{29}^{29} \mathrm{H}_{50} \mathrm{O}_{2}$ & 429 & $\checkmark$ & $x$ \\
\hline
\end{tabular}

compounds are common between mother plant and tissue culture plant, but interestingly seventeen (17) compounds were exclusively present in tissue culture plant of which a number of compounds are of potential therapeutic significance. Several phytochemicals belonging to long chain fatty moiety and their derivatives such as Hexadecanoic acid; Dodecanoic acid; Tetradecanoic acid; Heptanedioic acid; Octanedioic acid; Adipic acid etc has been identified in the samples. Interestingly, these long chain fatty acids play an important role in plant development [26]. linoleic acid (LA), oleic acid (OA), squalene and stigmasterol are the main bioactive compounds having different medicinal properties. LA is one of the essential fatty acids that human need in diet. Deficiency of LA may lead to growth retardation, infertility, skin and kidney degeneration and abrupt changes in fatty acid composition of lipids [27]. Besides, LA has been reported to suppress human tumor [28] and lung tissue cancer [29]. Another metabolite, OA has been reported to have potential protective effect against breast cancer and colon carcinomas in rats [30,31]. 3-Hydroxybutyric acid has anti-stress activity [32]. In addition, squalene and stigmasterol were reported as potent antioxidants as well as beneficial against several carcinogens $[33,34]$. Hence, it seems likely that the tissue culture plant contain plenty of medicinally important constituents which might be a good source of natural medicine.

\section{Molecular Docking}

The compounds detected by GC-MS for the mother plant and the tissue cultured progeny largely contain the same set of phytocompounds indicating that the basic chemical architecture of both is same. However, some of the compounds present in tissue cultured plant were missing in the mother plant (Table 6). Among them interestingly 3-Hydroxybutyric acid and Pyroglutamic acid are also present. They are both reported for anti-stress activity and their presence indicates the intelligent development scheme for the micropropagated progeny $[35,32]$. To further understand their chemical behavior from a different perspective we conducted in-silico molecular docking tests. Here the receptor protein used is Brain-derived neurotrophic factor (BDNF), which is reported to have an upper hand in depression and stress related lifestyle hazards [32]. The two compounds are seen to have good interactions with our BDNF receptor, 3-Hydroxybutyric acid has a binding affinity of $-4.4 \mathrm{kcal} / \mathrm{mol}$ and Pyroglutamic acid has a binding affinity of $-4.7 \mathrm{kcal} / \mathrm{mol}$ (Fig. 4). So, it can be inferred that the 3-Hydroxybutyric acid and Pyroglutamic acid present in the micropropagated plants can have a potential to bind with BDNF receptor. Hence, besides having all the therapeutic uses of the plant itself, the tissue cultured plants can possess an added anti-stress property in itself. 


\section{CONCLUSION}

The present study is the first report of establishment of standard protocol for in-vitro regeneration of C. thomsoniae. The regenerated plantlets were healthy and RAPD and ISSR analysis showed that there was virtually no difference among the micropropagated plantlets and the mother plant of $C$. thomsoniae and thus can be concluded that the in-vitro regenerated plantlets were genetically stable and identical to their parental counterpart. Potential medicinal molecules derived during the regeneration process of $C$. thomsoniae can be a biotic, aseptic and low cost source of phytochemical for pharmaceutical industry.

\section{AUTHOR CONTRIBUTIONS}

PK, AKC, MB and TM carried out the research, collection and analyzing data and wrote the first draft of the manuscript. AKC carried out statistical and docking part of the manuscript. AS conceived of the study, and participated in its design and coordination helped to draft the manuscript. All authors read and approved the final manuscript.

\section{CONFLICT OF INTEREST}

The authors declare no conflict of interest.

\section{REFERENCES}

1. Sagreiya KP. Forests and Forestry. National Book Trust, India; 2005

2. Kar P, Goyal AK, Das AP, Sen A. Antioxidant and pharmaceutical potential of Clerodendrum L.: An overview. Int J Green Pharma2014;8: 210-216.

3. Koranski DS. Growth and flowering of Clerodendrum thomsoniae. Ph.D. Disertation, University of Wisconsin, Madison: 1976.

4. Bailey LH, Bailey EZ. Hortus Third. McMillan Publishing, N.Y.; 1977

5. Riffle RL. The Tropical Look. Timber Press, Portland, Oregon; 1998.

6. Tian J, Zhao QS, Zhang HJ, Lin ZW, Sun HD. New cleroindicins from Clerodendrum indicum. J Nat Prod1997;60: 766-769.

7. Dey P, Chaudhuri D, Tamang S, Chaudhuri TK. Mandal N In vitro antioxidant and free radical scavenging potential of Clerodendrum viscosum. Int J Pharm Bio Sci 2012; 3:454-471.

8. Singh MK, Khare G, Iyer SK, Sharwan G, Tripathi DK. Clerodendrum serratum: A clinical approach. J App Pharm Sci 2012; 02:11-15.

9. Nath SC, Bordoloi DN. Clerodendron colebrookianum, a folk remedy for the treatment of hypertension in North Eastern India. Int J Pharmacogn 1991; 29:127-129.

10. DeFilipps RA, Maina SL, Crepin J. Medicinal plants of the Guianas (Guyana, Surinam, French Guiana). Washington, DC: Department of Botany, National Museum of Natural History, Smithsonian Institution 2004.

11. Reynolds A, Laurie C, Mosley RL, Gendelman HE. Oxidative stress and the pathogenesis of neurodegenerative disorders. Int Rev Neurobiol 2007; 82: 297-325.

12. Belmaker RH, Agam G. Major depressive disorder. N Engl J Med 2008; 358:55-68.

13. Murashige T, Skoog F. A revised medium for rapid growth and bioassay with tobacco tissue cultures. Plant Physiol 1962;15:473-497.
14. Lloyd GB, McCown BH. Commercially feasible micropropagation of mountain laurel, Kalmia latifolia by use of shoot tip culture. Proc Inter Plant Prop Soc 1980; 30:421-427.

15. Mishra T, Goyal AK, Sen A. Somatic Embryogenesis and Genetic Fidelity Study of theMicropropagated Medicinal Species Canna indica. Horticulturae2015;1:3-13.

16. Kar P, Dey P, Misra AK, Chaudhuri TK, Sen A. Phytometabolomic fingerprinting of selected actinorhizal fruits popularly consumed in North-East India. Symbiosis2016; 70:159-168.

17. Angelucci F, Aloe L, Vasquez PJ, Mathé AA. Mapping the differences in the brain concentration of brain-derived neurotrophic factor (BDNF) and nerve growth factor (NGF) in an animal model of depression. Neuroreport 2000; 11:1369-1173.

18. Trott O, Olson AJ. Auto Dock Vina: improving the speed and accuracy of docking with a new scoring function, efficient optimization, and multithreading. J Comput Chem (2010; 31:455-461.

19. Srinath $G$, Sridhar $V$, Renuka R. In vitro propagation of the medicinal herb- Clerodendrum inerme. Advanced Biotech2009; 9:21-23.

20. Sharma M, Rai SK, Purshottam DK, Jain M, Chakrabarty D, Awasth A, Sharma AK. In vitro clonal propagation of Clerodendrum serratum (Linn.) Moon (barangi): a rare and threatened medicinal plant. Acta Physiologiae Plantarum 2009; 31(2):379-383.

21. Nataraj M, Kher MM, da Silva JAT. Micropropagation of Clerodendrum L. species: a review. Rendiconti Lincei 2016: 27(2): 169-179.

22. Thomas TH, Blakesley D. Practical and potential uses of cytokinins in agriculture and horticulture. Br Plant Growth Regul Group Monogr 1987; 14:69-83.

23. Mao AA, Wetten A, Fay M, Caligari PDS. In vitro propagation of Clerodendrum colebrookianum Walp, a potential natural antihypertension medicinal plant. Plant Cell Rep 1995; 14:493-496.

24. Baburaj S, Ravichandran P, Selvapandian M. In vitro adventitious shoot formation from leaf cultures of Clerodendrum inerme (L) Gaertn. Indian J Exp Biol 2000: 38(12):1274-1276.

25. Goyal AK, Pradhan S, Basistha BC, Sen A. Micropropagation and assessment of genetic fidelity of Dendrocalamus strictus (Roxb.) nees using RAPD and ISSR markers. 3 Biotech2015; 5:473-482.

26. Bach L, Faure JD. Role of very-long-chain fatty acids in plant development, when chain length does matter. Comptes Rendus Biologies 2010; 333:361.

27. Dobryniewski J, Szajda SD, Waszkiewicz N, Zwierz K. Biology of essential fatty acids (EFA). Przegl Lek 2007; 64:91-99.

28. Tsuzuki T, Tokuyama $Y$, Igarashi M, Miyazawa T. Tumor growth suppression by $\alpha$-eleostearic acid, a linolenic acid isomer with a conjugated triene system, via lipid peroxidation. Carcinogenesis $2004 ; 25: 1417-1425$

29. Cesano A, Visonneau S, Scimeca JA, Kritchevsky D, Santoli D. Opposite effects of linoleic acid and conjugated linoleic acid on human prostatic cancer in SCID mice. Anticancer Res 1998; 18:14291434.

30. Martin-Moreno JM, Willett WC, Gorgojo L, Banegas JR, RodriguezArtalejo F, Fernandez-Rodriguez JC, Maisonneuve P, Boyle P. Dietary fat, olive oil intake and breast cancer risk. Int J Cancer 1994; 58: 774-780.

31. Reddy BS, Maeura Y. Tumor promotion by dietary fat in azoxymethaneinduced colon carcinogenesis in female F344 rats: influence of amount and source of dietary fat. J Natl Cancer Inst 1984; 72: 745-750.

32. Sleiman SF, Henry J, Al-Haddad R, El Hayek L, Haidar EA, Stringer T, Ulja D, Karuppagounder SS, Holson EB, Ratan RR, Ninan I. Exercise promotes the expression of brain derived neurotrophic factor (BDNF) through the action of the ketone body $\beta$-hydroxybutyrate. Elife 2016; 5:1-21.

33. Amarowicz R. Squalene: A natural antioxidant?. Eur J Lipid Sci Tech 2009; 111:411-412.

34. Yoshida $Y$, Niki E. Antioxidant effects of phytosterol and its components. J Nutr Sci Vitaminol 2003; 49:277-280.

35. Pepeu G, Spignoli G. Nootropic drugs and brain cholinergic mechanisms. Prog Neuropsychopharmacol Biol Psychiatry 1989; 13:77-88. 